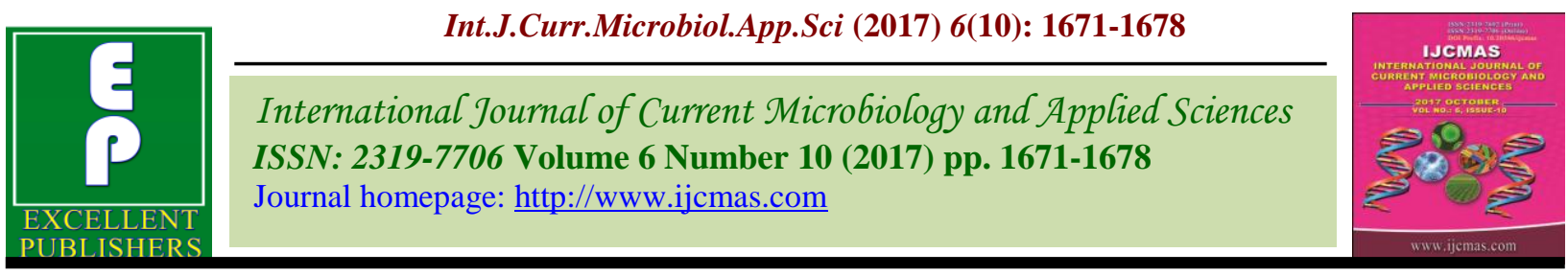

Original Research Article

https://doi.org/10.20546/ijcmas.2017.610.202

\title{
Yield Response of Cucumber (Cucumis sativus) Crop under Drip and Flood Irrigation System
}

\author{
N. Hari*, G. Manoj Kumar and K. Krupavathi \\ College of Agricultural Engineering, Bapatla, ANGRAU, A.P., India \\ *Corresponding author
}

\begin{tabular}{|c|c|}
\hline & A B S T R A C T \\
\hline $\begin{array}{l}\text { Drip irrigation, } \\
\text { Uniformity, Wetting } \\
\text { pattern, Application } \\
\text { rate and root } \\
\text { distribution. }\end{array}$ & \multirow{3}{*}{$\begin{array}{l}\text { A commercial drip irrigation system was evaluated for small scale cucumber crop at } \\
\text { College of Agricultural Engineering field irrigation laboratory, located at Bapatla, Guntur } \\
\text { district, Andhra Pradesh state during February } 2013 \text { to April } 2013 \text {. In the field study, an } \\
\text { attempt was made to evaluate the performance of the irrigation system in terms of on the } \\
\text { uniformity distribution, wetting pattern, sphericity and root distribution. The statistic } \\
\text { uniformity and absolute uniformity were within the acceptable limits. It was observed } \\
\text { revealed that inline emitter used in the study, can wet horizontal distance up to } 50 \mathrm{~cm} \text { from } \\
\text { the source, while the depth of wetting increased with the rate of application. The root } \\
\text { distribution was observed to be confined mainly to } 60 \mathrm{~cm} \text { sphere and the optimum rate of } \\
\text { water to be application was ensured under the prevailing conditions. The average } \\
\text { sphericity of cucumber fruit was observed } 0.96 \text {, which was } 3.12 \% \text { higher than flood } \\
\text { irrigation crop. }\end{array}$} \\
\hline Article Info & \\
\hline $\begin{array}{l}\text { Accepted: } \\
\text { 17 September } 2017 \\
\text { Available Online: } \\
\text { xx October } 2017\end{array}$ & \\
\hline
\end{tabular}

Introduction

Land and water are the basic needs of Agriculture and economic development of any country. India only has 2.4 percent of land mass and 4 percent fresh water resource of the world. We are however required to support 17 percent of the world population and growing at 2 percent/annum. Agriculture uses about $70-80$ percent of total available water. The maximum reliable irrigation potential in India has been estimated at 113.5 $\mathrm{M}$ ha. This is targeted to be reached by the year 2010 A.D of this potential 73.5 $\mathrm{M}$ ha. Will be from surface Water resources $(58.5 \mathrm{M}$ ha. from major and medium resources and only $15 \mathrm{M}$ Ha from minor resources) and 40 $\mathrm{M}$ ha. From the ground water resources (all from minor resources). This can be increased to about 150 - $160 \mathrm{M}$ ha gross irrigated area by the year 2050 A.D. for the required production. This can be achieved by introducing advance systems of irrigation like micro irrigation and other improved water management practices.

It ensures 30 - 70 percent saving in water, 25 100 percent increase in yields and $15-30$ percent reduction in operating and crop production costs. Resultantly it can double the area under micro irrigation as well as improve quality of end product. It can lead to value added exports, result in greater social equality, conservation of precious natural resources, promote and protect environment and ecology and can transform agriculture. It 
can ensure cost efficient and sustainable agricultural development in the country and result in higher addition to GDP. It generates higher employment at all levels and add value to human efforts.

The drip irrigation system was introduced in the year 1940 by Dr. Symcha Blass an Israel Engineer and later on it spread to different parts of the world. In India drip irrigation was introduced in the early seventies at the Agricultural Universities and other research institutions. These may be online drip, inline drip, micro tube, pressure compensating, nonpressure compensating and self-flushing types. For irrigating widely spaced crops like mango, coconut, banana, grapes and other high value vegetable crops this system is most suitable. Drip irrigation works under low to medium pressures i.e. varies from 0.5 to $2 \mathrm{~kg} /$ $\mathrm{cm}^{2}$. In line source tubing irrigation system, emitting devices are prefixed along the lateral lines. For row crops, closely spaced crops like vegetables, cotton, flower crops and shrubs this system is suitable ideally. At present most of the vegetables in India are grown using flood methods of irrigation. In these methods major portion of water is lost by evaporation and deep percolation, resulting lower irrigation efficiencies.

Moreover there is a tendency to apply more water when it is available in large quantities. Under such conditions the grower tends to increase the irrigation interval which creates water stresses resulting in poor yields. Due to these reasons, there is a great need to use the micro irrigation systems for growing vegetable crops.

\section{Materials and Methods}

It is a regular practice for small scale formers during summer in Bapatla region. The experiment was conducted in the Field irrigation laboratory, College of Agricultural
Engineering, Bapatla from the second week of February to the second week of April, 2013.Geographically Bapatla is located at altitude of $15^{0} 54^{1} \mathrm{~N}$ and longitude of $80^{0} 30^{1}$ $\mathrm{E}$ with an altitude of $4.5 \mathrm{~m}$ above mean sea level. The experimental site lies in humid subtropical area. The summers are dry and hot, whereas winter is cool. The experimental site consists of sandy soil and well-drained soil. The field was prepared for loosening the soil and for removal of weeds prior to sowing by using rotovator. About $100 \mathrm{~kg}$ of Farm yard manure was applied throughout the field having area of $300 \mathrm{~m}^{2}\left(1^{\text {st }}\right.$ plot- $20 \times 10 \mathrm{~m}$ (drip irrigation), $2^{\text {nd }}$ plot- $10 \times 10 \mathrm{~m}$ (flood irrigation) after one week again the plot was tilled with rotator to mix the dried Farm yard manure thoroughly in the soil. The experimental field was divided into two plots of 200 and $100 \mathrm{~m}^{2}$ area each. The $200 \mathrm{~m}^{2}$ plot was irrigated by using inline drippers whereas the $100 \mathrm{~m}^{2}$ plot was irrigated by flood method. The plant to plant and row to row spacing for inline drip irrigated plot was $0.4 \mathrm{~m}$ and $2 \mathrm{~m}$ whereas for flood irrigated plot was $1 \mathrm{~m}$ for both plant to plant and row to row.

\section{Water application and irrigation scheduling for different irrigation systems}

Water requirement of crop in inline drip irrigation was obtained by estimating the potential Evapotranspiration using modified Penman's method. Which is based on the daily data of maximum and minimum temperature, relative humidity, sunshine hours and wind velocity is given by:

$\mathrm{ET}_{\mathrm{p}}=\mathrm{C}\left[\mathrm{WRn}+(1-\mathrm{W}) \mathrm{f}(\mathrm{u})\left(\mathrm{e}_{\mathrm{a}}-\mathrm{e}_{\mathrm{d}}\right)\right]$

Where,

ET $\mathrm{p}=$ Potential evapotranspiration in $\mathrm{mm} /$ day

$\mathrm{W}=$ Temperature related weighing factor 
$\mathrm{R}_{\mathrm{n}}=$ Net radiation in equivalent evaporation $\mathrm{mm} /$ day

$\mathrm{f}(\mathrm{u})=$ Wind related function

$\left(e_{a}-e_{d}\right)=$ Difference between the saturation vapor pressure at mean air

$\mathrm{C}=$ Adjustment factor to compensate the effect of day and night weather.

Water requirement of plant in lit/plant/day = ETp x Crop coefficient x Gross area per plant

$=\frac{\text { Application }}{\text { dipper discharge }(\mathrm{L} / \mathrm{hr})} \quad$ rate

By taking water application efficiency in micro irrigation as $90 \%$ amount of water to be applied to a plant in lit / day $=\frac{\text { Water requirement of plant }}{\text { Application efficiency }}$

Inline drip irrigation operating period Amount of water to be applied to a plant

Discharge of emitting device

Irrigation time (hours)

$=\frac{\text { Volume of available water }(\mathrm{L})}{\text { Dripper discharge rate }(\mathrm{L} / \mathrm{hour})}$

In flood method water was applied to plants at rate of $48 \mathrm{lit} / \mathrm{min}$ by sprinkling water with plastic pipe which is generally followed by local farmers. The irrigation scheduling is assumed in this system was based on 50 percent depletion of available soil moisture at response of $0-40 \mathrm{~cm}$ depth of root zone.

\section{Crop details}

Cucumber (Cucumis sativus), is a popular vegetable belongs to the family of Cucurbitacea and called as Kamal Kakdi in Hindi, Dosakaya in Telugu. It is known for its high nutritive value. It is the mostly cultivated vegetable in the world after potato. In Andhra
Pradesh it was cultivated in 26,763 ha and getting 2.54 lakhs tones of production annually. Cucumber can be grown under wide agro-climatic conditions. High and low temperature causes poor fruit setting. High temperature with low humidity and dry winds damage the floral parts and resulting into poor yield. It can be sustainable up to $35^{\circ}$ temperature.

\section{Sowing time}

The cucumber is cultivated both as a summer and rainy season crop and the seed is sown according to type of crop. The sowing period for summer crop ranges between January to February whereas for rainy season crop it is in between June to July. For hilly regions it is sown in month of April.

\section{Cultural management of cucumber}

The seed rate is $2.5-4 \mathrm{~kg} / \mathrm{ha}$ and selected plot was $300 \mathrm{~m}^{2}\left(20 \times 10=200 \mathrm{~m}^{2}\right.$ and $10 \times 10=100$ $\left.\mathrm{m}^{2}\right), 120 \mathrm{~g} / 300 \mathrm{~m}^{2}$ seed rate required. The seed was sown manually and two to three seeds were sown in each pit. Farm Yard Manure (FYM) was added at the time of soil preparation. $50 \mathrm{~kg} / \mathrm{ha}$ Super, $25 \mathrm{~kg} / \mathrm{ha}$ DAP and $50 \mathrm{~kg} / \mathrm{ha}$ phosphorus was given at the time of sowing and remaining half amount was given after 30 days of sowing. Timely irrigation is necessary for a successful growth of the crop according to their requirement. The irrigation was given daily for both 200 $\mathrm{m}^{2}$ and $100 \mathrm{~m}^{2}$ plot with an application rate of $1000 \mathrm{~L} /$ day and $800 \mathrm{~L} /$ day. It is a process of removal of weeds by performing weeding and hoeing operation regularly during the growth period.

It is a process of collecting matured fruit from the plant.

Picking of fruits may be done at light yellow stage when fruits are fully developed are to be disposed of at distant markets. 
For local markets fruits are harvested at green stage when some portion is yellow and fruit is not fully ripe.

For processing purposes picking be done at ripe or full ripe stage when fruits have developed maximum color and turns soft.

\section{Wetting pattern}

In determination of wetting pattern, 10 emitter points of cucumber cultivation with known discharge rates were selected randomly. Water was applied continuously at $0.5,1,1.5$ and 2 liters and same treatments where given to two emitters at a time. From the strickle source, sampling points were marked laterally with $5 \mathrm{~cm}$ intervals as 5,10 and $15 \mathrm{~cm}$ respectively at either side of trickle source. In each point soil samples were taken at depths of 5, 10 and $15 \mathrm{~cm}$ using an auger at $6 \mathrm{hr}$ after irrigation. Moisture content was measured by gravimetric method. For improving the growth of plants in sandy soil, $5 \mathrm{~kg}$ super and $4 \mathrm{~kg}$ of 17 - 17 - 17 fertilizers applied on split dose basis $300 \mathrm{~m}^{2}$ cropped area (Khan et al., 1975) at the stages of 30 and 60 days after seedling.

Micro nutrients soluble fertilizer of $20 \mathrm{ml}$ of insta and $20 \mathrm{ml}$ of monikam diluted with 5 liters of water and sprayed over crop surface. First spray was used 30 days after sowing and one more sprays with 30 days. This soluble fertilizer improved crop yields both qualitatively and quantitatively and control flower drop and improve disease resistance to plant.

\section{Plant growth}

For studying the effect of irrigation treatment on crop growth characteristics, 10 days interval of systematic observations from selected plants in each plot were made on the growth of crop. The growth was measured by measuring the length of the creep.

\section{Fruit weight}

To study the effect of irrigation on fruit weight the number of fruits from each plot were collected and average weight of fruit was measured by using the electrical balance.

\section{Sphericity of fruit}

The sphericity of the fruit was calculated by using venire calipers with least count of $0.001 \mathrm{~mm}$. Sphericity may be defined as the ratio of the diameter of a sphere of the same volume as that of the particle and the diameter of the smallest circumscribing sphere or generally the largest diameter of the particle (Sahay and Sing., 2004).

Spericity $=\frac{(\mathbb{a b t}) 1 / 2}{\mathbb{1}}$

Where,

$l=$ largest intercept,

$b=$ largest intercept perpendicular to $l$ and

$t=$ largest intercept perpendicular to both $l$ and b.

\section{Root length and its distribution}

For studying the response of irrigation treatment on root distribution, trench was made around the selected plants in each plot after completing the crop period. After removing the root system from soil, it was carefully arranged on a graph paper and root distribution was measured.

\section{Water use efficiency}

The term water use efficiency denotes the production per unit of water applied. It is expressed as the weight of crop produce per unit depth of water over a unit area., $\mathrm{kg} / \mathrm{cm}$ per hectare. 
water use efficiency $=\frac{Y}{W R}$

Where,

$Y=Y i e l d$ of the crop $(\mathrm{kg} / \mathrm{ha})$,

$\mathrm{WR}=\mathrm{Water}$ requirement of the crop $(\mathrm{cm})$.

\section{Results and Discussion}

This chapter deals with the results of experimental observations that have been analyzed and discussed in relation to the cucumber crop under in line drip irrigation and flood method of irrigation the vegetative growth of the plants, wetting pattern yield and quality characteristics of the crop, root zone distribution and water use efficiency during the crop period mainly discussed in this chapter.

\section{Vegetative growth parameters of cucumber crop under different irrigation methods}

The experiment findings obtained from the present study have been discussed in the following heads

\section{Wetting pattern}

The vertical distribution of water in sandy soil is shown in figure 1 (selected plot is of sandy soil). Water applied for inline drip irrigation method for 1 hour interval is of 4 liters and in flood irrigation method for 1 hour is of 6-8 liters. when compared between these two methods water given for flood irrigation is more than inline drip irrigation method but the efficiency of water distribution vertically was (the average wetting pattern for inline drip method and flood methods are 1.08 and 1.24) 0.16 times more in inline drip irrigation than flood irrigation method (Table 1).

\section{Quality characteristics of the fruit weight of fruit}

The fruit weight of cucumber under different irrigation treatment was presented in Table 2 and the average was found to be 185.33 and 174.64 gms in inline drip irrigation and flood irrigation method.

The values of the percentage increase in fruit weight of cucumber over flood irrigation method to be $5.76 \%$ (Table 2).

Table.1 Wetting pattern for inline and flood irrigation methods

\begin{tabular}{|c|c|c|c|c|c|c|c|c|c|}
\hline \multirow[t]{2}{*}{$\begin{array}{l}\text { S. } \\
\text { No }\end{array}$} & \multirow[t]{2}{*}{$\begin{array}{l}\text { Depth } \\
(\mathrm{cm})\end{array}$} & \multicolumn{2}{|c|}{$\begin{array}{l}\text { Wt of empty } \\
\text { box }\end{array}$} & \multicolumn{2}{|c|}{$\begin{array}{c}\text { Wt of empty } \\
\text { box+soil } \\
\text { sample }\end{array}$} & \multicolumn{2}{|c|}{$\begin{array}{c}\text { Wt of empty } \\
\text { box+soil } \\
\text { sample }\end{array}$} & \multicolumn{2}{|c|}{ Wetting pattern } \\
\hline & & $\begin{array}{l}\text { Inline } \\
\text { drip }\end{array}$ & flood & $\begin{array}{l}\text { Inline } \\
\text { drip }\end{array}$ & flood & $\begin{array}{l}\text { Inline } \\
\text { drip }\end{array}$ & flood & $\begin{array}{c}\text { Inline } \\
\text { drip }\end{array}$ & flood \\
\hline 1 & 5 & 26.28 & 22.51 & 46.28 & 42.51 & 44.88 & 39.98 & 1.40 & 2.53 \\
\hline 2 & 10 & 23.64 & 21.90 & 43.64 & 41.90 & 42.70 & 38.24 & 0.94 & 3.66 \\
\hline 3 & 15 & 22.45 & 28.20 & 42.45 & 48.20 & 41.12 & 46.88 & 1.33 & 1.32 \\
\hline 4 & 20 & 25.96 & 19.90 & 45.96 & 39.90 & 43.95 & 38.83 & 2.01 & 1.07 \\
\hline 5 & 25 & 22.16 & 21.02 & 42.16 & 41.02 & 40.78 & 40.39 & 1.38 & 0.63 \\
\hline 6 & 30 & 29.72 & 25.37 & 49.72 & 45.37 & 48.33 & 45.17 & 1.39 & 0.20 \\
\hline 7 & 35 & 22.76 & 22.93 & 42.76 & 42.93 & 42.36 & 42.33 & 0.40 & 0.60 \\
\hline 8 & 40 & 26.07 & 24.01 & 46.07 & 44.01 & 45.58 & 43.41 & 0.49 & 0.60 \\
\hline 9 & 45 & 22.54 & 23.41 & 42.54 & 43.41 & 42.15 & 42.89 & 0.39 & 0.52 \\
\hline \multicolumn{8}{|c|}{ Average } & 1.08 & 1.24 \\
\hline
\end{tabular}


Table.2 Weight of fruit sample (grams)

\begin{tabular}{|l|l|l|l|}
\hline S.No & Method of irrigation & $\begin{array}{l}\text { Average fruit weight of } \\
\text { cucumber(gms) }\end{array}$ & $\begin{array}{l}\text { Percentage increase in fruit } \\
\text { weight over flood method }\end{array}$ \\
\hline 1 & Inline drip & 185.33 & $5.76 \%$ \\
\hline 2 & Flood & 174.64 & ----- \\
\hline
\end{tabular}

Table.3 Sphericity of cucumber fruits in both the method

\begin{tabular}{|l|l|l|l|}
\hline S.No & $\begin{array}{l}\text { Method of } \\
\text { irrigation }\end{array}$ & $\begin{array}{l}\text { Average sphericity of } \\
\text { cucumber }\end{array}$ & $\begin{array}{l}\text { Percentage increase in sphericity } \\
\text { cucumber over flood irrigation method }\end{array}$ \\
\hline 1 & Inline drip & 0.96 & $3.12 \%$ \\
\hline 2 & Flood & 0.93 & ---- \\
\hline
\end{tabular}

Table.4 Yield of cucumber crop (kgs)

\begin{tabular}{|l|l|l|l|}
\hline \multicolumn{1}{|c|}{ S.No } & Harvesting after 60 days & Drip irrigation $(\mathrm{kg})$ & Flood irrigation $(\mathrm{kg})$ \\
\hline 1 & 60 & 22 & 20 \\
\hline 2 & 70 & 20 & 17 \\
\hline 3 & 80 & 17 & 16 \\
\hline Average weight & $\mathbf{5 9}$ & $\mathbf{5 3}$ \\
\hline
\end{tabular}

Table.5 Growth of cucumber for both drip and traditional method at 10 days interval

\begin{tabular}{|l|l|l|l|}
\hline S.NO & Days after seedling & In line drip irrigation $(\mathrm{cm})$ & Flood method $(\mathrm{cm})$ \\
\hline 1 & 10 & 3.1 & 2.6 \\
\hline 2 & 20 & 28.3 & 27.7 \\
\hline 3 & 30 & 40.5 & 41.2 \\
\hline 4 & 40 & 61.6 & 62.6 \\
\hline 5 & 50 & 90.5 & 84.4 \\
\hline 6 & 60 & 100.20 & 95.2 \\
\hline
\end{tabular}

Table.6 Water use efficiency of cucumber crop in different irrigation treatment

\begin{tabular}{|l|l|r|r|}
\hline S. No & Description & \multicolumn{2}{|c|}{ Treatment } \\
\cline { 3 - 4 } & & Inline drop irrigation & Flood irrigation method \\
\hline 1 & ${\text { Area, }{ }^{2}}^{2}$ & 100 & 100 \\
\hline 2 & Plant population & 120 & 150 \\
\hline 3 & Irrigation interval, days & daily & Daily \\
\hline 4 & Application rate, $\mathrm{mm} /$ day & 5 & 4 \\
\hline 5 & Effective rain fall, mm & - & -240 \\
\hline 6 & Total depth of irrigation during crop & 300 & 5.3 \\
\hline 7 & Season, mm & & 22.08 \\
\hline 8 & Yield, kg/ha & 19.6 & \\
\hline
\end{tabular}


Fig.1 vertical depth vs. moisture content of the soil

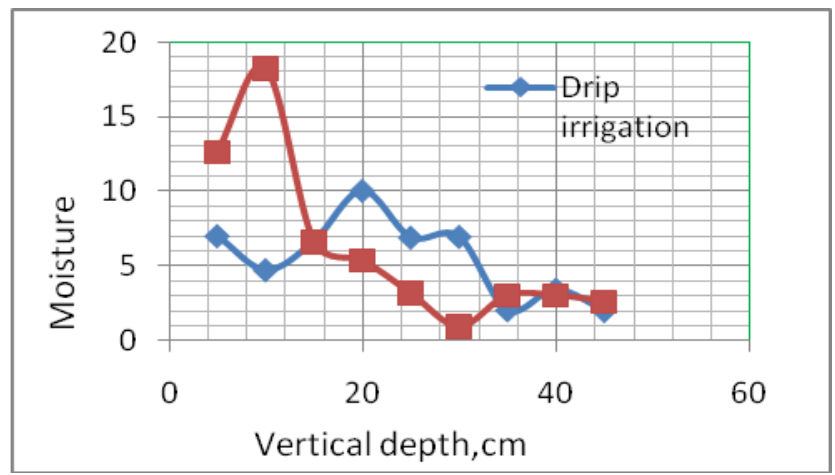

Fig.2 Yield vs. harvesting period of cucumber crop

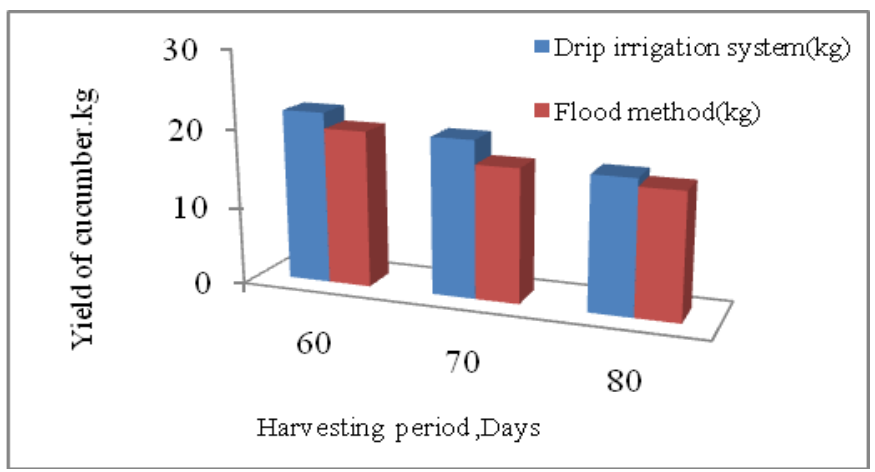

Fig.3 Plant growth vs. days after seedling in different irrigation treatment

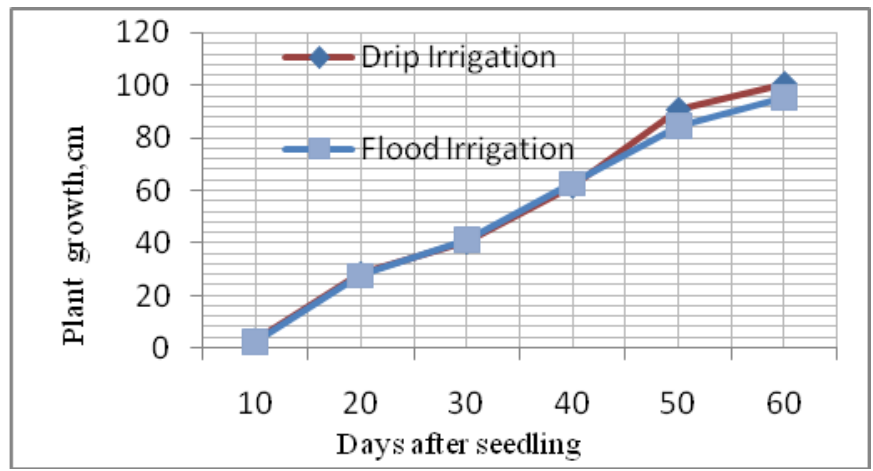

\section{Sphericity of the fruit}

The fruit weight of cucumber under different irrigation treatment was presented in Table 2 and the average was found to be 0.96 and 0.93 in inline drip irrigation and flood irrigation method. The values of the percentage increase in fruit weight of cucumber over flood irrigation method to be $3.12 \%$ (Table 3 ).
Yield of cucumber in different irrigation treatment

The total yield of cucumber for one picking is represented in Table 4 in different irrigation treatments. The total yields obtained from an area of $200 \mathrm{~m}^{2}$ experimental plots were 59 and $53 \mathrm{kgs}$ for inline drip irrigation and flood irrigation method. Based on enquiries with 
farmers assuming 3 such pickings will be done and the yield per hectare where estimated 59 and $53 \mathrm{q} / \mathrm{ha}$ in inline drip irrigation and flood irrigation method (Fig. 2).

The percentage increase in yield over flood method of irrigation was found to be $10.17 \%$ for inline drip irrigation system respectively.

\section{Plant growth}

The growth of cucumber crop was measured at every 10 days intervals in both inline drip irrigation and flood irrigation method shown below Table 5 the mean growth of cucumber crop at the time of harvesting 60 days after seedling was 100.20 and $95.2 \mathrm{~cm}$ in both inline drip irrigation and flood irrigation method.

The maximum plant growth was observed in inline drip irrigation method because of better lateral distribution $(0.40 \mathrm{~m})$ of water in the plant root zone. The percentage increase in plant growth was 5\% in inline drip irrigation method over flood irrigation method (Fig. 3).

\section{Water use efficiency}

The water utilized by the crop was generally described in terms of water use efficiency.

The water use efficiency achieved in different irrigation treatment was presented in Table 6 . The percentage of water saving over flood irrigation method was found to be $35.30 \%$ in inline drip irrigation method.

From the experimental observations it was concluded that about $35.3 \%$ of water saved in inline drip over flood method of irrigation. About $10.16 \%$ of higher yields obtained in inline drip over flood method. The water use efficiency increased in case of inline drip irrigation method 2.48 times than the flood method of irrigation system. Higher vegetative growth was observed in inline drip method than flood method. Less weed growth was observed in inline drip irrigation system.

\section{References}

Jadhav, S.S., Guptal, G.B., and Chougule, A.A., 1992. Cost Economics of the drip irrigation system for tomato crop. Proceeding of the $11^{\text {th }}$ international Congress on the use of plastic in Agriculture, New Delhi, and P.171-176.

Maheswar appa, H.P., Mathew, A.C. and Gopala sundaram, P., 1997. Moisture movement in active root zone of coconut under drip irrigation in lateral sandy soil. Journal of plantation crops, P.201-204.

Michel, A.M., 2008. Irrigation theory and practice, Vikas publishing house Pvt.Ltd., New Delhi, pp.652-661.

Sivanappan, R.K., Padma kumari, O., and Kumar, V., 1972. Drip irrigation, Kirthi publishing house Pvt. Ltd., P.275-278.

\section{How to cite this article:}

Hari, N., G. Manoj Kumar and Krupavathi, K. 2017. Yield Response of Cucumber (Cucumis sativus) Crop under Drip and Flood Irrigation System. Int.J.Curr.Microbiol.App.Sci. 6(10): 1671-1678. doi: https://doi.org/10.20546/ijcmas.2017.610.202 